Original Research Paper

\title{
Potentiality of Biogas as Renewable Energy Technology and its role for the Conservation of Environment
}

\author{
${ }^{1}$ Maheshwor Poudel, ${ }^{2}$ Pabitra Adhikari and ${ }^{3}$ Ramesh Man Singh \\ ${ }^{I}$ Central Department of Environmental Science, Tribhuvan University, Kathmandu, Nepal \\ ${ }^{2}$ College of Applied Sciences-Nepal, Tribhuvan University, Kathmandu, Nepal \\ ${ }^{3}$ Centre for Energy and Environment - Nepal, Kathmandu, Nepal
}

Article history

Received: 05-11-2016

Revised: 29-11-2016

Accepted: 13-12-2016

Corresponding Author:

Maheshwor Poudel

Central Department of

Environmental Science,

Tribhuvan University,

Kathmandu, Nepal

Email: poudel.maheshwor@gmail.com

\begin{abstract}
The study shows the status of biogas as a Renewable Energy Technology (RET) and its role in the conservation of environment by reducing the consumption of fuelwood and Greenhouse Gases (GHGs) emission. 95 household survey, 10 key informant interviews, 3 focus group discussion and direct observatory technique were used for primary data collection. Fuelwood was found to be dominant energy resource which comprises $93.73 \%$ of total energy and rest $6.27 \%$ of energy was supplied by other sources of energy. The fuelwood consumption was 71.29 GJ per year per household which emits $646.1 \mathrm{tCO}_{2} \mathrm{e}$. The study shows that the annual GHGs reduction was found $7.62 \mathrm{tCO}_{2} \mathrm{e}$ per biogas plant. On the basis of population of the agriculture based livestock of the study area, there was the possibility of 84 biogas plants of size $6 \mathrm{~m}^{3}$ which can reduce the total $638.82 \mathrm{tCO}_{2} \mathrm{e}$ of GHGs emission per year. The study showed that the use of biogas technology can save $46.67 \%$ of fuelwood which can conserve 217.32 tons of fuelwood per year per household. The simple payback period in term of fuelwood saved for the construction of $6 \mathrm{~m}^{3}$ biogas plant was found to be only 4.08 years. Thus, the reduction or substitution of fuelwood as a primary energy resource, reduction of the GHGs emission and high potentiality of biogas in the area with adequate number of agriculture based livestock clearly indicates that biogas is as a suitable RET in reducing GHGs emission and helps in mitigating climate change.
\end{abstract}

Keywords: Fuelwood, Greenhouse Gases, Biogas, Renewable Energy Technology

\section{Introduction}

Energy is an important development indicator, which provides vital inputs for survival and economic development. Energy is needed for almost all the activities of humankind, so there has been search for new and more convenient source of energy since the early history. Every sector of development like domestic, agriculture, transport, industrial, communication is directly or indirectly based on the energy supply. Human activities particularly the intense use of carbon based energy sources and unsustainable use of biomass resources is increasing greenhouse gases in the earth's atmosphere resulting global warming in a way that could profoundly affect the global climatic system (Parikh, 2004).
The overall energy consumption of Nepal is largely dominated by the subsistence use of traditional forms of energy such as fuelwood, agricultural residues and animal waste. The intensive use of fossil fuels and unsustainable use of biomass resources from human activities are emitting GHGs which are causing greenhouse effect in the earth's atmosphere resulting global warming process which in turn have resulted the climate change as indicated by various scientific studies (Shakya and Shrestha, 2006). Fuelwood harvesting has been identified as one of the most significant causes of forest decline in rural areas of developing countries (Bhatta and Sachan, 2004). In Nepal, about $87.1 \%$ of total energy are of traditional biomass energy resources, of which, fuelwood is the main source of biomass energy 
resources providing about $77 \%$ of the total energy demand exerting immense pressure on the forest resources and $12.26 \%$ of total energy are of commercial energy resources and only $0.7 \%$ of total energy consumption comes from the renewable energy sources in Nepal (WECS, 2010).

Renewable Energy Technologies are energy providing technologies that utilize energy sources in ways that do not deplete the earth's natural resources and are considered environmentally benign. Renewable energy sources are indigenous and can contribute towards reduction in dependency of fossil fuels. These sources are sustainable. It can be ensured that they can be used almost indefinitely without degrading the environment (REA, 2009). Biogas, solar power, wind power, biobriquettes and micro level hydropower are categorised into renewable energy resources in Nepal. Biogas and biobriquettes are examples of modern interventions, wherein traditional energy sources undergo transformations into modern types of fuels. The RETs based on the locally available resources with increased efficiency and environment friendly alternatives seems very feasible for controlling GHGs emission and protecting environment.

Biogas is a form of clean cooking mechanism, an eco-friendly sustainable source of renewable energy, economically and environmentally compatible to use. It typically refers to a mixture of different gases produced by the breakdown of organic matter in the absence of oxygen. It is produced out of raw materials like organic waste, manure, municipal waste, plant material, sewage, green waste, food waste etc and can be used for multiple purposes like thermal, electric, etc. The slurry that the biogas system produces is a convenient source of organic fertilizer which is a key factor on multiplying the agro-productions maintaining the environmental sustainability. Biogas can be produced by anaerobic digestion with anaerobic organisms, which digest material inside a closed system, or fermentation of biodegradable materials (NNFCC, 2011).

The research is focused on determining the amount of energy consumed in terms of fuelwood and GHGs emission among the biogas user and non user households in the hilly region of Nepal. It will help to calculate the fuelwood consumption among biogas user and non user households and find out the potentiality of biogas as an alternative source of energy in the study area.

\section{Methodology}

\section{Study Area}

The study was carried out at Sankhupati Chaur Village Development Committee (VDC) of Kavrepalanchok (Fig. 1). The area of Sankhupati Chaur VDC is $6.95 \mathrm{~km}^{2}$ and is located between the latitude $27^{0} 34^{\prime} 24.3$ ' $\mathrm{N}$ to $27^{0} 57^{\prime} 05^{\prime \prime} \mathrm{N}$ and longitude $85^{\circ} 33$ '26.5' $\mathrm{E}$ to $84^{0} 56^{\prime} 02$ " $\mathrm{E}$ and the elevation of 1523 masl.

The VDC is dominated by warm temperate climate with maximum temperature of $32^{\circ} \mathrm{C}$ and minimum temperature of $0^{\circ} \mathrm{C}$. The average annual rainfall is $1200 \mathrm{~mm} .41 .58 \%$ of VDC is covered by forest. The major forest types include Pinus roxburthii Forest, Schima castanopsis Forest, Alnus nepalensis Forest, Pinus wallichii Forest, Rodhodendron spp. Forest. The species are mainly fodder species like Ficus nemoralis, Alnus nepalensis, Ficus semicordata, Michelia champcta, Castanopsis tribuloides, Melia azedarach and Morus alba.

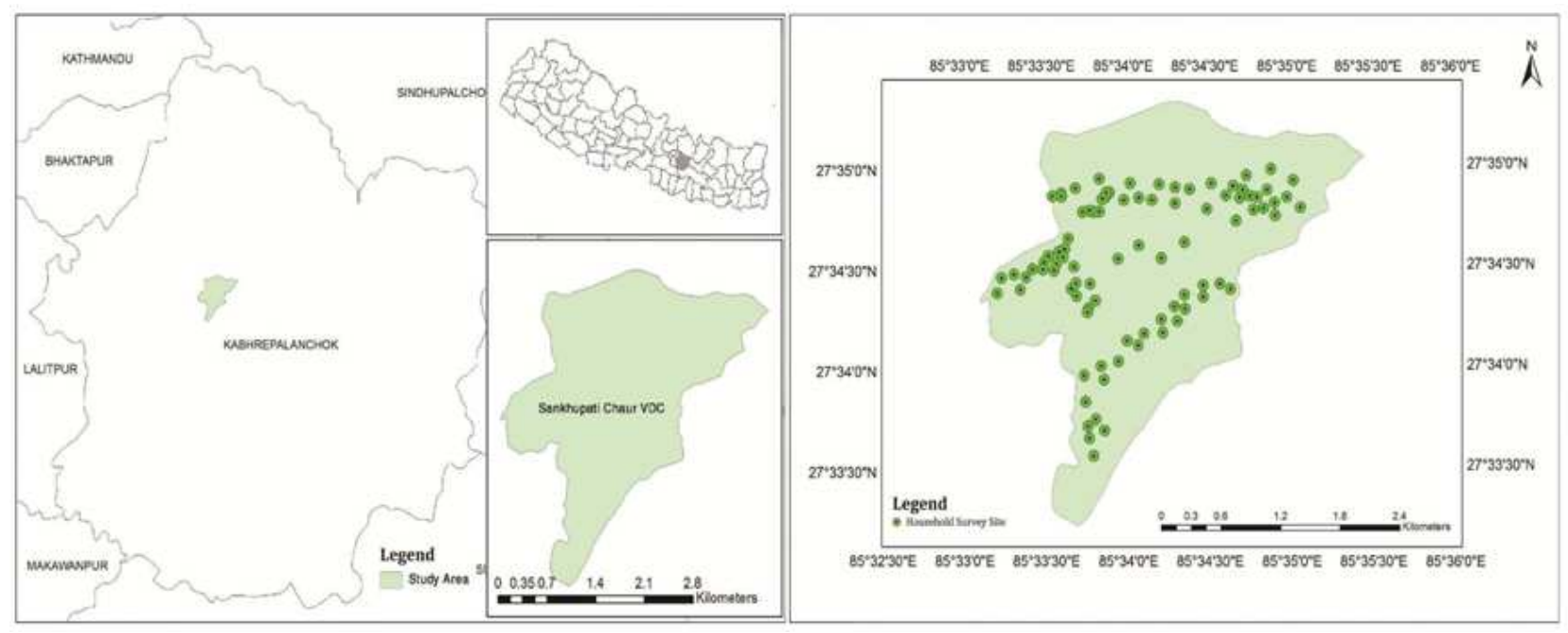

Fig. 1. Sampled Household of Study Area 


\section{Data Collection}

Simple random purposive sampling was used to determine the sample size. Among 722 households of Sankhupati Chaur VDC, 95 households were taken as a sample household (Arkin and Colton, 1963). Out of 95 households, 15 households of marginalized people within the VDC were also selected, considering they were not in random selection. It is because marginalized people are using the less efficient technology of energy consumption and they have less capacity to adapt the efficient energy consumption technology.

A semi-structured questionnaire was used for data collection in household survey. Direct observation about the energy consumption practice and its environmental impacts was noted during the field visit. The weight of 1 bhari (one bundle of fuelwood carried by a person) was determined by taking average weight of 10 different bharis of fuelwood. Key informants were interviewed with structured checklists in order to verify the gathered relevant information. Focus Group Discussion was also carried out with the local stakeholders to get information about the past and present condition of forest, stoves use, training and awareness campaign on RETs and change in socio-economic status of community. Check list was prepared to include RETs trend, environmental impacts and socioeconomic status.

\section{Data Analysis and Presentation}

\section{Estimation of Biogas Potential}

The sampled households were asked about the number of cattle owned to determine the daily dung production. Considering the daily dung production of 10 $\mathrm{kg}$ per cattle by assuming the animals were partly stall fed and partly grazed (BSP, 2009) and depending on average number of adult and young cattle, the total amount of dung produced in the area was estimated and the gas produced from the dung was calculated considering the gas produced per $\mathrm{kg}$ of dung to be 0.032 $\mathrm{m}^{3}$ (Warner et al., 1989):

Gas produced per $\mathrm{kg}$ of dung $=0.0230-0.040 \mathrm{~m}^{3}$ (Average value $=0.032 \mathrm{~m}^{3}$ )

\section{Calculation of amount of Dung required to generate $1 \mathrm{~m}^{3}$ of Gas}

$0.032 \mathrm{~m}^{3}$ of Gas is produced from $1 \mathrm{~kg}$ of Dung Thus, $31.25(\sim 31) \mathrm{kg}$ of dung is required to produce $1 \mathrm{~m}^{3}$ of Gas.

\section{Calculation of Amount of Fuelwood Saved}

Amount of fuelwood saved was calculated on the basis of energy content on fuelwood as stated by
Vidhya and Gautam (2011) i.e., 1 ton of dry fuelwood contains 16.75 GJ of energy.

\section{Calculation of Number of Trees Saved and Areas of Forest Protected}

The equivalent forest area saved was estimated on the basis of the study carried out by WES (2004) on impact of biogas on forest which states that 1 ha of forest contains 32.81 tons of fuelwood.

The estimated number of trees saved through potential biogas plants was based on the estimation of an annual saving of 11.6 trees per biogas plant (Devkota, 2007).

\section{Estimation of GHGs Emission Reduction}

$1 \mathrm{~kg}$ of fuelwood generates $1.518 \mathrm{~kg}$ equivalent of carbon emission (Smith et al., 2000). GHGs emission reduction in terms of carbon dioxide was obtained as follows:

- GHGs Emission Reduction = Amount of fuelwood saved $\times$ GHGs emission per $\mathrm{kg}$ of fuelwood

\section{Calculations and Analytical Process:}

- Average weight of 1 bhari of fuelwood was determined by weighing randomly 10 bhari of fuelwood and found to be $30.8 \mathrm{~kg}$

- Annual income saving from reduction in fuelwood was calculated at the local rate of NRs. 140 per bhari

- Per capita fuelwood consumption = (average fuelwood consumption per family per day $\times$ total number of families in the ecosystem)/total number of people in the ecosystem (Maharjan, 2008)

- The estimated number of technically potential biogas plant was based on the daily dung available from cattle as $10 \mathrm{~kg}$ dung/cattle (BSP, 2009)

- Emission factor for combustion of fuels were also converted to $\mathrm{CO}_{2} \mathrm{e}$ as given by IPCC (1996) and Smith et al. (2000)

- The methane leakage calculation was based on the methane leakage calculated by Devkota (2003).

\section{Result and Discussion}

\section{Energy Consumption Pattern}

Fuelwood, Electricity, Kerosene, Liquefied Petroleum Gas (LPG) and Biogas were the energy sources used in Sankhupati Chaur VDC. The total annual energy consumption among the sampled household was found to be 7225.72 GJ which refers to 14.06 GJ per year per capita energy consumption (Table 1). The annual per capita energy consumption from the fuelwood was 13.18 GJ, whereas electricity, kerosene, LPG and biogas share $0.21 \mathrm{GJ}, 0.04 \mathrm{GJ}, 0.16 \mathrm{GJ}$ and $0.48 \mathrm{GJ}$ respectively. 


\section{Possibility of Biogas Plant}

The study showed that the possibility of total 84 biogas plants among the sampled households. Out of which 27 biogas plants had already been constructed so the possibility of another 57 biogas plants of size $6 \mathrm{~m}^{3}$ in the sampled household of study area. It was calculated by assuming the total dung produced per animal per day to be $10 \mathrm{~kg}$ and the amount of dung required to run one 6 $\mathrm{m}^{3}$ of biogas plant is $31 \mathrm{~kg} /$ day (BSP, 2009) (Table 2).

\section{Amount of GHGs Reduction from Biogas Plant}

All together $205.62 \mathrm{tCO}_{2} \mathrm{e}$ per year of GHGs emission was reduced from the 27 biogas plants of sampled households of Sankhupati Chaur VDC (Table 3).

\section{In Condition (Estimation of GHGs Reduction)}

If all the potential biogas plant of size $6 \mathrm{~m}^{3}$ were constructed from the dung produced annually then the total amount of GHGs reduction will be $638.82 \mathrm{tCO}_{2} \mathrm{e}$ per year.

\section{Estimation of Number of Trees Saved and Areas of Forest Protected}

The study showed that the total potentiality of 84 biogas plants was found in Sankhupati Chaur VDC. If all these 84 biogas plant of size $6 \mathrm{~m}^{3}$ were constructed then total number of trees saved will be 974.4 per year. Hence, the forest area protected per household per year will be 0.0789 ha (Table 4).

\section{In Condition (Estimation of Fuelwood Saved)}

If all the 84 potential biogas plants were constructed from the dung produced annually, the amount of fuelwood saved would be 217.32 tons per year per household.

\section{Fuelwood Consumption among Biogas User and Non-User Households}

The comparison was done between biogas user and non-user households (20 households from each group) which showed that non-biogas user households use 5544 $\mathrm{kg}$ of fuelwood annually, whereas biogas users use only
$2956.8 \mathrm{~kg}$ of fuelwood. Therefore, there was the saving of $2,587.2 \mathrm{~kg}$ of fuelwood which is equivalent to Nepalese Rupees (NRs.) 11,760 per year per household. The study showed that the use of biogas saved $46.67 \%$ of fuelwood per year per household (Table 5).

\section{Estimation of GHGs Emission from Energy Sources}

The per capita GHGs emission was found to be $1209.11 \mathrm{kgCO}_{2} \mathrm{e}$ per year. The study showed that $613791.76 \mathrm{kgCO}_{2} \mathrm{e}$ was emitted with the consumption of $404342.40 \mathrm{~kg}$ fuelwood annually, whereas 5263.97 $\mathrm{kgCO}_{2} \mathrm{e}$ was emitted from with $404342.40 \mathrm{~kg}$ of LPG. Likewise, consumption of $514.80 \mathrm{~L}$ of kerosene per year emits $1278.76 \mathrm{kgCO}_{2} \mathrm{e}$. Similarly, biogas emits 1088.86 $\mathrm{kgCO}_{2} \mathrm{e}$ from the consumption of $244879.20 \mathrm{MJ}$ of energy. Only $0.53 \mathrm{kgCO}_{2} \mathrm{e}$ emitted with the consumption of $29520 \mathrm{kWh}$ of electricity (Table 6).

\section{Economic Analysis}

From the field survey it was found that, the average total cost for the construction of biogas plant of capacity of $6 \mathrm{~m}^{3}$ was NRs. 48,000 in the hilly region of Nepal. This shows that the simple payback period in term of fuelwood saved for the construction of $6 \mathrm{~m}^{3}$ biogas plant will be only 4.08 years (Table 7). Nepal Government provides the subsidy amount of NRs. 12,000 in the hilly region for the installation of biogas plant and the subsidy was provided in terms of construction materials and labor cost. Thus, the simple payback period in term of fuelwood saved for the construction of $6 \mathrm{~m}^{3}$ biogas plant will be only 3.06 years only (if subsidy is provided).

\section{Impact of Biogas on Environment and Health}

Biogas helps to minimize pressure on forests by addressing one of the drivers of deforestation and forest degradation, promote sustainable management of forests and carbon financing for the sustainable management. As biogas is a clean form of energy and Nepal is gaining huge amount of revenue from CDM Project. If claimed under CDM, Nepal can get huge revenue in terms of certified reduction rate of US\$ 7 per $\mathrm{tCO}_{2}$.

Table 1. Energy consumption pattern

\begin{tabular}{llllll}
\hline $\begin{array}{l}\text { Energy } \\
\text { Sources }\end{array}$ & $\begin{array}{l}\text { Consumption } \\
\text { per day }\end{array}$ & $\begin{array}{l}\text { Consumption } \\
\text { per month }\end{array}$ & $\begin{array}{l}\text { Consumption } \\
\text { per year }\end{array}$ & $\begin{array}{l}\text { Annual Energy } \\
\text { Consumption in GJ }\end{array}$ & $\begin{array}{l}\text { Per Capita Energy } \\
\text { Consumption in GJ }\end{array}$ \\
\hline Fuelwood & $1123.17 \mathrm{~kg}$ & $33695.20 \mathrm{~kg}$ & $404.34 \mathrm{ton}$ & 6772.86 & 13.18 \\
Electricity & $82 \mathrm{Units}$ & $2460 \mathrm{kWh}$ & $29.52 \mathrm{MWh}$ & 106.27 & 0.21 \\
Kerosene & $1.43 \mathrm{~L}$ & $42.90 \mathrm{~L}$ & $0.51 \mathrm{KL}$ & 18.49 & 0.04 \\
LPG & $4.70 \mathrm{~kg}$ & $140.86 \mathrm{~kg}$ & $1.69 \mathrm{ton}$ & 83.22 & 0.16 \\
Biogas & $680.22 \mathrm{MJ}$ & $20406.52 \mathrm{MJ}$ & $244.88 \mathrm{GJ}$ & 244.88 & 0.48 \\
Total & & & & 7225.72 & 14.06 \\
\hline
\end{tabular}

Table 2 . Biogas potentiality

\begin{tabular}{|c|c|c|c|c|c|}
\hline Livestock & $\begin{array}{l}\text { Total No. } \\
\text { of livestock }\end{array}$ & $\begin{array}{l}\text { Dung produced } \\
\text { per animal per day }\end{array}$ & $\begin{array}{l}\text { Total dung } \\
\text { produced day }\end{array}$ & $\begin{array}{l}\text { Dung required to } \\
\text { run one } 6 \mathrm{~m}^{3} \text { plant }\end{array}$ & $\begin{array}{l}\text { Potential of } 6 \mathrm{~m}^{3} \\
\text { of biogas plant }\end{array}$ \\
\hline Cow / Ox / Buffalo & 261 & 10 & 2610 & 31 & 84.1 \\
\hline
\end{tabular}


Table 3. Amount of GHGs reduction

\begin{tabular}{llll}
\hline Biogas size $\left(\mathrm{m}^{3}\right)$ & Hilly area $\left(\mathrm{tCO}_{2} \mathrm{e} /\right.$ year/plant $)$ & No. of plants & Total reduction $\left(\mathrm{tCO} \mathrm{C}_{2} \mathrm{e} /\right.$ year $)$ \\
\hline 4 & 5.43 & 4 & 21.72 \\
6 & 7.6 & 18 & 136.80 \\
8 & 9.42 & 5 & 47.10 \\
Total & & 27 & 205.62 \\
\hline
\end{tabular}

Table 4. Estimation of equivalent area of forest protected

\begin{tabular}{ll}
\hline Particulars & Comparing biogas user and non- biogas user households \\
\hline Annual Fuelwood Saving per Household (tons/year) & 2.5872 \\
Equivalent Forest Area Protected per Household (ha/year) & 0.0789 \\
\hline
\end{tabular}

Table 5. Fuelwood consumption among biogas user and non-user households

\begin{tabular}{lll}
\hline Particulars & Biogas user household & Non-biogas user household \\
\hline Average household fuelwood consumption per month (kg) & 246.4 & 462 \\
Average household fuelwood consumption per year (kg) & 2956.8 & 5544 \\
Expenditure in fuelwood per year per household (NRs.) & 13,440 & 25,200 \\
Fuelwood saved per year per household (kg) & 2587.2 & - \\
\% of Fuelwood saved & $46.67 \%$ & - \\
Expenses saved per year per household (NRs.) & 11,760 & - \\
\hline
\end{tabular}

Table 6. Total $\mathrm{CO}_{2} \mathrm{e}$ emission from energy sources

\begin{tabular}{lllll}
\hline Energy sources & Annual energy consumptions & $\mathrm{GHGs}$ & $\mathrm{CO}_{2} \mathrm{e}$ & Annual GHGs emission $\left(\mathrm{kgCO}_{2} \mathrm{e}\right)$ \\
\hline Fuelwood & $404342.40 \mathrm{~kg}$ & $\mathrm{CO}_{2}$ & $1.406 \mathrm{~kg} / \mathrm{kg}$ & \\
& & $\mathrm{CH}_{4}$ & $0.084 \mathrm{~kg} / \mathrm{kg}$ & 613791.76 \\
& & $\mathrm{~N}_{2} \mathrm{O}$ & $0.028 \mathrm{~kg} / \mathrm{kg}$ & \\
Electricity & $29520 \mathrm{kWh}$ & $\mathrm{CO}_{2}$ & $0.0000179(\mathrm{ef})$ & 0.53 \\
Kerosene & $514.80 \mathrm{~L}$ & $\mathrm{CH}_{4}$ & $0.007 \mathrm{~kg} / \mathrm{L} / \mathrm{L}$ & 1278.76 \\
& & $\mathrm{~N}_{2} \mathrm{O}$ & $0.020 \mathrm{~kg} / \mathrm{L}$ & \\
& & $\mathrm{CO}_{2}$ & $3.0689 \mathrm{~kg} / \mathrm{kg}$ & 5263.97 \\
LPG & $1690.37 \mathrm{~kg}$ & $\mathrm{~N}_{2} \mathrm{O}$ & $0.0452 \mathrm{~kg} / \mathrm{kg}$ & 1088.86 \\
& & & & 621423.89 \\
Biogas & & & & \\
Total & $244879.20 \mathrm{MJ}$ & & &
\end{tabular}

Table 7. Payback Period of $6 \mathrm{~m}^{3}$ Biogas Plant

\begin{tabular}{lllll}
\hline $\begin{array}{l}\text { Plant Capacity } \\
\left(\mathrm{m}^{3}\right)\end{array}$ & $\begin{array}{l}\text { Amount of Fuelwood } \\
\text { saved per year per } \\
\text { household }(\mathrm{kg})\end{array}$ & $\begin{array}{l}\text { Amount of Expenses } \\
\text { saved per year per } \\
\text { household (NRs.) }\end{array}$ & $\begin{array}{l}\text { Total cost for construction } \\
\text { of biogas plant (NRs.) }\end{array}$ & $\begin{array}{l}\text { Pay Back } \\
\text { Period in years }\end{array}$ \\
\hline 6 & 2587.2 & 11,760 & 48,000 & 4.08 \\
\hline
\end{tabular}

Biogas brings multiple benefits on the social, environmental and economic fronts. The clean and fresh air inside kitchen, management of wastes like agricultural wastes, organic waste, manure, municipal waste, plant material, sewage, green waste and food waste, obviously gives the better health and sanitation in the community. Indoor air pollution can be reduced by more than $80 \%$ compared to kitchen having traditional cooking stoves, which consequently improves the health of the people with the reduction of eye related problems and serious respiratory diseases. On the other hand, time spending on kitchen while using the efficient energy technology can be minimized which can be utilized for the better care of children and other income generating activities.

\section{Conclusion}

The study showed that per capita energy consumption was found to 14.06 GJ with per capita household energy consumption of 76.06 GJ. Out of which $93.73 \%$ of the total energy was of traditional form of biomass energy i.e., fuelwood which emits $646.1 \mathrm{tCO}_{2} \mathrm{e}$ of GHGs per year. On the basis of the population of the agriculture based livestock, the possibility of 84 biogas plants of size $6 \mathrm{~m}^{3}$ was found in the study area which can reduce the total emission of $638.82 \mathrm{tCO}_{2} \mathrm{e}$ of greenhouse gases per year. The study showed that biogas technology can save $46.67 \%$ of fuelwood in comparison with the household who does not use biogas as an energy source. The simple 
payback period in term of fuelwood saved for the construction of $6 \mathrm{~m}^{3}$ biogas plant was found to be 4.08 years only (3.06 years if subsidy is given), which indicates that biogas can be the economic and most reliable renewable energy technology which can either reduce or substitute fuelwood as a primary energy source and reduce the emission of GHGs and helps in mitigating climate change. So authority body of government of the developing country like Nepal should provide special support for the construction of biogas in the local communities and helps to promote biogas as an efficient RET.

\section{Acknowledgement}

The authors would like to thank Central Department of Environmental Science, Tribhuvan University for providing the opportunity to carry out this research. The authors are equally thankful to Centre for Energy and Environment Nepal for all the technical support to conduct the research work. The authors are thankful to all the participants of this study for their immense support and providing required information to conduct this research.

\section{Author's Contributions}

Maheshwor Poudel: Manuscript preparation, data acquisition, interpretation and analysis.

Pabitra Adhikari: Data acquisition and analysis.

Ramesh Man Singh: Manuscript revision.

\section{Ethics}

This paper is original and includes unpublished materials. The corresponding author confirms that all other authors have read and approved the manuscript.

\section{Reference}

Arkin, H. and R.R. Colton, 1963. Tables for Statisticians. Second Edition, Barnes and Noble, New York, ISBN-10: 0064600750, pp: 168.

Bhatta, B.P. and M.S. Sachan, 2004. Firewood Consumption along an Altitudinal Gradient in Mountain Villages of India. Biomass and Bioenergy 27: 69-75. DOI: 10.1016/j.biombioe.2003.10.004

BSP, 2009. Biogas as Renewable Source of Energy in Nepal: Theory and Development. Biogas Support Program, Lalitpur, Nepal.

Devkota, G.P., 2007. Renewable Energy Technology in Nepal: An Overview and Assessment, pp: 7.

Devkota, G.P., 2003. Final Report on Analysis of Biogas Leakages from Household Digesters. Winrock International, Kathmandu, Nepal.
IPCC, 1996. Revised 1996 IPCC Guideline for National Greenhouse Gas Inventories. Reporting Instruction, Workbook and Reference Manual, Intergovernmental Panel on Climate Change.

Maharjan, R., 2008. Study on Energy Consumption Pattern and its Impact on Environment with Reference to Okharpauwa VDC, Nuwakot.College of Applied Science, Tribhuvan University, Kathmandu, Nepal.

NNFCC, 2011. NNFCC Renewable Fuels and Energy Factsheet: Anaerobic Digestion. National Non-Food Crops Centre.

Parikh, J., 2004. Clean Development Mechanism and Sustainable Development. Integrated Research and Action for Development, New Delhi.

REA, 2009. Energy and Environment. Renewable Energy Association.

Shakya, S.R. and J.N. Shrestha, 2006. Contribution of Renewable Energy Technologies for GHG Mitigation in Nepal. First National Conference on Renewable Energy Technology for Rural Development, RETRUD-06, October, 2006, pp: 318-325.

Smith, K.R., R. Uma, V.V.N. Kishore, J. Zhang, V. Joshi, M.A.K. Khalil, 2000. Greenhouse Implications of Household Stoves: An Analysis for India. Annual Review of Energy and the Environment 25: 741-763. DOI: 10.1146/annurev.energy.25.1.741.

Vidhya, S. and R.M. Gautam, 2011. Energy Outlook of Nepal. First Edition, Informal Sector Research and Study Centre, Kathmandu, Nepal, pp: 315.

Warner, U., U. Stöhr and N. Hees, 1989. Biogas Plants in Animal Husbandary. GATE/GTZ, Gmbh.

WES, 2004. Nepal Biogas Programme, CDM Baseline Study 2003. Winrock and Eco Securities.

WECS, 2010. Energy Sector Synopsis Report 2010. Water and Energy Commission Secretariat. GoN, Kathmandu Nepal. 